\title{
CROPS AND SOILS RESEARCH PAPER Genetic improvement of bread wheat yield and associated traits in Spain during the 20th century
}

\author{
M. SANCHEZ-GARCIA ${ }^{1}$, C. ROYO ${ }^{1}$, N. APARICIO ${ }^{2}$, J. A. MARTÍN-SÁNCHEZ ${ }^{1}$ AND F. ÁLVARO ${ }^{1}$ * \\ ${ }^{1}$ IRTA (Institute for Food and Agricultural Research and Technology), Field Crops Section, Centre UdL-IRTA, Rovira Roure, \\ 191, E-25198 Lleida, Spain \\ 2 ITACyL, Ctra. Burgos, Km. 119, E-47071 Valladolid, Spain
}

(Received 8 July 2011; revised 6 February 2012; accepted 14 March 2012; first published online 17 April 2012)

\section{SUMMARY}

A collection of 26 wheat genotypes widely grown in Spain during the 20th century was evaluated in eight contrasting environments in order to quantify breeding achievements in yield and associated traits. From 1930 to 2000 , yield increased at a rate of $35 \cdot 1 \mathrm{~kg} / \mathrm{ha} / \mathrm{yr}$ or $0 \cdot 88 \% / \mathrm{yr}$, but estimations of relative genetic gain (RGG) were environment-dependent. RGG estimated for yield were positively associated with the average minimum daily temperatures from sowing to heading in the testing environments $\left(R^{2}=0 \cdot 81 ; P<0 \cdot 01\right)$. The number of grains/spike and the number of spikes $/ \mathrm{m}^{2}$ increased at a rate of $0.60 \% / \mathrm{yr}$ and $0.30 \% / \mathrm{yr}$, respectively, while grain weight remained unchanged. The present study detected two main episodes of yield improvement during the century. The first one coincided with the introduction, during the 1950s, of the first improved cultivars derived from intraspecific crosses, which increased the yield of landraces by $30 \%$ due to an increase of c. $58 \%$ in the number of grains/spike, accompanied by a $16 \%$ reduction in grain weight. These initial cultivars (termed 'old-bred' in a previous study by Sanchez-Garcia et al. 2012) exhibited a higher harvest index (HI), increased from $0 \cdot 25$ to $0 \cdot 40$, but maintained the same aboveground biomass at maturity as the landraces (despite reducing both plant height and the number of tillers/plant) due to increases in the proportion of tillers bearing spikes. The second yield gain occurred after the introduction, in the early 1970s, of semi-dwarf germplasm from CIMMYT (International Maize and Wheat Improvement Centre) and some French cultivars. This new germplasm further reduced plant height, improved $\mathrm{HI}$ up to 0.45 and increased the number of tillers/plant while maintaining their rate of fertility, thus resulting in a yield gain of c. $37 \%$. The cultivars released during the last decade of the century did not contribute to significant yield improvements.

\section{INTRODUCTION}

Bread wheat (Triticum aestivum L.) is a traditional crop in Spain, which is the fifth wheat producer of the European Union, devoting 1.4 million hectares to the species in 2010 (EUROSTAT 2011). However, during the 20th century investments in wheat breeding in Spain were irregular and genotype replacement relied mostly on the introduction of foreign germplasm.

Wheat breeding activities in Spain started in the 1920s, mainly with the classification of local landraces and bulk selection within them (Royo \& Briceño-Félix

* To whom all correspondence should be addressed. Email: fanny. alvaro@irta.cat
2011). However, the early breeding programmes were interrupted by the Spanish Civil War (1936-39), which severely damaged the incipient efforts of cereal researchers to produce improved wheat genotypes. During the two decades after the war, breeding activities were devoted to further improving traditional wheat genotypes through selection and hybridization, and foreign improved cultivars, mainly from Italy and France, were successfully introduced. Some of the cultivars released during the 1950s (such as the Italian cultivars Mara and Impeto and the French cultivar Estrella) carried the Rht8c dwarfing gene and probably the photoperiod-insensitive gene PpD1 (Worland et al. 1998), which has been reported to affect plant 
height, cycle length and crop productivity (Borojevic \& Borojevic 2005). The advent of CIMMYT semi-dwarf germplasm in the late 1960s had a great impact on Spanish agriculture. It was rapidly adopted in southern Spain, but the French germplasm continued to be grown in northern Spain (Royo \& Briceño-Félix 2011). The major dwarfing genes Rht1B and Rht1D were introduced with CIMMYT germplasm, and have been reported to result in yield increases of c. $15 \%$ in nearoptimal conditions (Worland \& Snape 2001). A study conducted in durum wheat, whose history is parallel to that of bread wheat, indicated that new sources of alleles were used in the crosses that led to the cultivars released in Spain since 1990 (Martos et al. 2005).

Understanding the crucial characteristics of the crop associated with the genetic gains achieved through breeding is an essential step for improving the current knowledge of yield-limiting factors and the design of future breeding strategies. Historical series of genotypes have been deployed and used in several countries to assess the genetic gains achieved during a period of time through selection and breeding (Austin et al. 1989; Donmez et al. 2001; Morgounov et al. 2010). However, information about gains in yield and related traits in Spain is scarce.

The number of grains $/ \mathrm{m}^{2}$ and, more precisely, the number of grains/spike, have been reported to be the main traits contributing to yield rises under a wide range of environmental conditions (Perry \& D'Antuono 1989; Donmez et al. 2001; Royo et al. 2007), whereas changes in grain weight have proven to be null (Austin et al. 1989; Brancourt-Hulmel et al. 2003) or even negative (Siddique et al. 1989; Royo et al. 2007). Increases in the number of spikes $/ \mathrm{m}^{2}$ of bread and durum wheat during the 20th century have also been detected, mainly under Mediterranean conditions (Perry \& D'Antuono 1989; Canevara et al. 1994; Royo et al. 2007), and they have been attributed to increases in the number of spikes/plant (Royo et al. 2007).

From the point of view of biomass production and allocation, past genetic gains in bread wheat yield have been associated widely with increases in harvest index $(\mathrm{HI})$ and decreases in plant height (Canevara et al. 1994; Brancourt-Hulmel et al. 2003). The introduction of dwarfing genes reduced the size of the vegetative organs, thus enhancing the availability of assimilates to the reproductive organs of the plant, expressed as a higher number of grains/spike (Álvaro et al. 2008a). Austin et al. (1980) proposed 0.62 as a theoretical upper limit for $\mathrm{HI}$, but $\mathrm{HI}$ rises beyond
$0 \cdot 50$ are difficult to attain (Fischer \& Edmeades 2010). However, in some countries current levels are close to this upper limit and further yield improvements must therefore be based on increasing biomass while maintaining $\mathrm{HI}$ (Pfeiffer et al. 2000; Shearman et al. 2005).

The uneven history of bread wheat introduction in Spain during the last century may have led to the boosting of different plant attributes in different phases, as has been reported in other countries where the paths followed to achieve yield gains during the last century differed across periods (Austin et al. 1989; Canevara et al. 1994). Through a study of the main periods of release of bread wheat genotypes in Spain, the objective of the present work was to quantify yield breeding progress during the 20th century and to identify the key traits associated with it.

\section{MATERIALS AND METHODS}

\section{Plant material}

A collection of 28 bread wheat genotypes representative of those most widely grown in Spain during the 20th century was assembled. The genotypes were grouped into four breeding periods: (i) Spanish landraces grown before 1940; (ii) initial cultivars derived from crosses, including those improved and grown from the mid-1940s until the Green Revolution (termed 'old-bred' in a previously published paper, Sanchez-Garcia et al. 2012); (iii) intermediate cultivars introduced in Spain from 1970 and mostly derived from semi-dwarf germplasm of CIMMYT and French cultivars; and (iv) modern cultivars, released during the last decade of the 20th century (Table 1).

\section{Experimental setup}

Twenty-six genotypes of the collection were tested in multi-location experiments harvested in 2006 and 2007, but sown in November or December of the previous year (Table 1). Experiments were conducted at four sites representative of the main bread wheat growing areas in Spain: Burgos, in the north, with cold winters and mild summers; Lleida in the north-east, where terminal stress was moderate and the plots were irrigated; Albacete in the south-east, with cold winters and very hot and dry summers; and Cordoba in the south-west, with warm winters and very hot summers (Table 2).

For a more detailed study, a subset of 16 genotypes representative of the entire collection (Table 1) was 
Table 1. Description of the genotypes used in the study and the breeding periods to which they belong

\begin{tabular}{|c|c|c|c|c|}
\hline Genotype & Pedigree & Origin & $\begin{array}{l}\text { Year of release } \\
\text { in Spain }\end{array}$ & Experiments* \\
\hline \multicolumn{5}{|c|}{ Local landraces } \\
\hline Aragon 03 & Selection of the landrace 'Catalan de Monte.' & Spain & $<1940$ & $\begin{array}{l}\text { Multi-location (ML) } \\
\text { and Lleida (LL) }\end{array}$ \\
\hline Barbilla & Landrace & Spain & $<1940$ & $M L$ and $L L$ \\
\hline Candeal & Landrace & Spain & $<1940$ & ML and LL \\
\hline Chamorro & Landrace & Spain & $<1940$ & $\mathrm{ML}$ \\
\hline Negrillo & Landrace & Spain & $<1940$ & $M L$ \\
\hline \multicolumn{5}{|l|}{ Initial } \\
\hline Mara & Autonomia/Aquila & Italy & 1947 & $\mathrm{LL}$ \\
\hline Impeto & Frassineto-405/Villa-glori & Italy & 1950 & ML and LL \\
\hline Estrella & $\begin{array}{l}\text { Mon-desir/Ardito//Mouton-a-epi-rouge/ } \\
\text { k-3/3/Mouton-epi-rouge }\end{array}$ & France & 1952 & ML and LL \\
\hline Pané 247 & L-4/Mentana & Spain & 1955 & ML and LL \\
\hline \multicolumn{5}{|l|}{ Intermediate } \\
\hline Siete Cerros & Penjamo-62/Gabo-55 & CIMMYT & 1969 & $M L$ \\
\hline Yecora & $\begin{array}{l}\text { Ciano-67(sib)//Sonora-64/Klein-rendidor/ } \\
\text { 3/Siete-cerros-66 }\end{array}$ & CIMMYT & 1972 & $\mathrm{LL}$ \\
\hline Cajeme & $\begin{array}{l}\text { Ciano-67(sib)//Sonora-64/Klein-rendidor/ } \\
\text { 3/Siete-cerros-66 }\end{array}$ & CIMMYT & 1972 & ML and LL \\
\hline Anza & $\begin{array}{l}\text { Lerma-rojo-64//Norin-10/Brevor/3/ } \\
\text { 3*Andes-enano }\end{array}$ & CIMMYT/USA & 1974 & ML and LL \\
\hline Astral & Fortunato/YGA/3/Florence/Aurore//G-4 & France & 1974 & $M L$ \\
\hline Marius & $\begin{array}{l}\text { Cadet//Thatcher/Vilmorin-27/3/Ariana/ } \\
\text { Fundulea }\end{array}$ & France & 1980 & ML and $L L$ \\
\hline Rinconada & Unknown & Spain & 1981 & ML and LL \\
\hline Alcalá & Unknown & Spain & 1984 & $M L$ \\
\hline Cartaya & Kuz/Buho//Kal/BB & CIMMYT & 1984 & $M L$ \\
\hline Soissons & lena/hn-35 & France & 1990 & ML and LL \\
\hline \multicolumn{5}{|l|}{ Modern } \\
\hline Bancal & Unknown & Spain & 1991 & $M L$ \\
\hline Pinzón & Unknown & Spain & 1992 & $M L$ \\
\hline Gazul & Unknown & Spain & 1992 & ML and LL \\
\hline Etecho & VPM/Talent//Fidel/3/Declic & France & 1995 & $M L$ \\
\hline Babui & Unknown & Spain & 1997 & $M L$ \\
\hline Berdun & Unknown & France & 1998 & $M L$ \\
\hline Isengrain & Apollo/Soissons & France & 1998 & ML and $\mathrm{LL}$ \\
\hline Craklin & Unknown & France & 1999 & $\mathrm{ML}$ \\
\hline Califa Sur & Unknown & Spain & 2001 & ML and LL \\
\hline
\end{tabular}

* ML=genotypes included in eight multi-location experiments in 2006 and 2007; LL=genotypes included in experiments conducted in Lleida in 2008 and 2009.

selected and further evaluated in four field experiments in Lleida during two additional crop seasons (2008 and 2009) under two contrasting water regimes: irrigated and rainfed. Irrigated experiments received supplementary water inputs of $150 \mathrm{~mm}$ in 2008 and $96 \mathrm{~mm}$ in 2009 (see details in Table 2).

All plots were sown in a randomized complete block design with three replications. Plots consisted of eight rows $5 \mathrm{~m}$ long and $0 \cdot 15 \mathrm{~m}$ apart. Sowing density was 350 seeds $/ \mathrm{m}^{2}$ in the multi-location experiments conducted in 2006 and 2007 and 450 seeds $/ \mathrm{m}^{2}$ in the experiments conducted in Lleida in 2008 and 2009. Experimental details are given in Table 2. Plots were mechanically harvested at ripening.

\section{Data recording}

All plots were mechanically harvested at ripening and yield was expressed as $120 \mathrm{mg} / \mathrm{g}$ of grain moisture. 


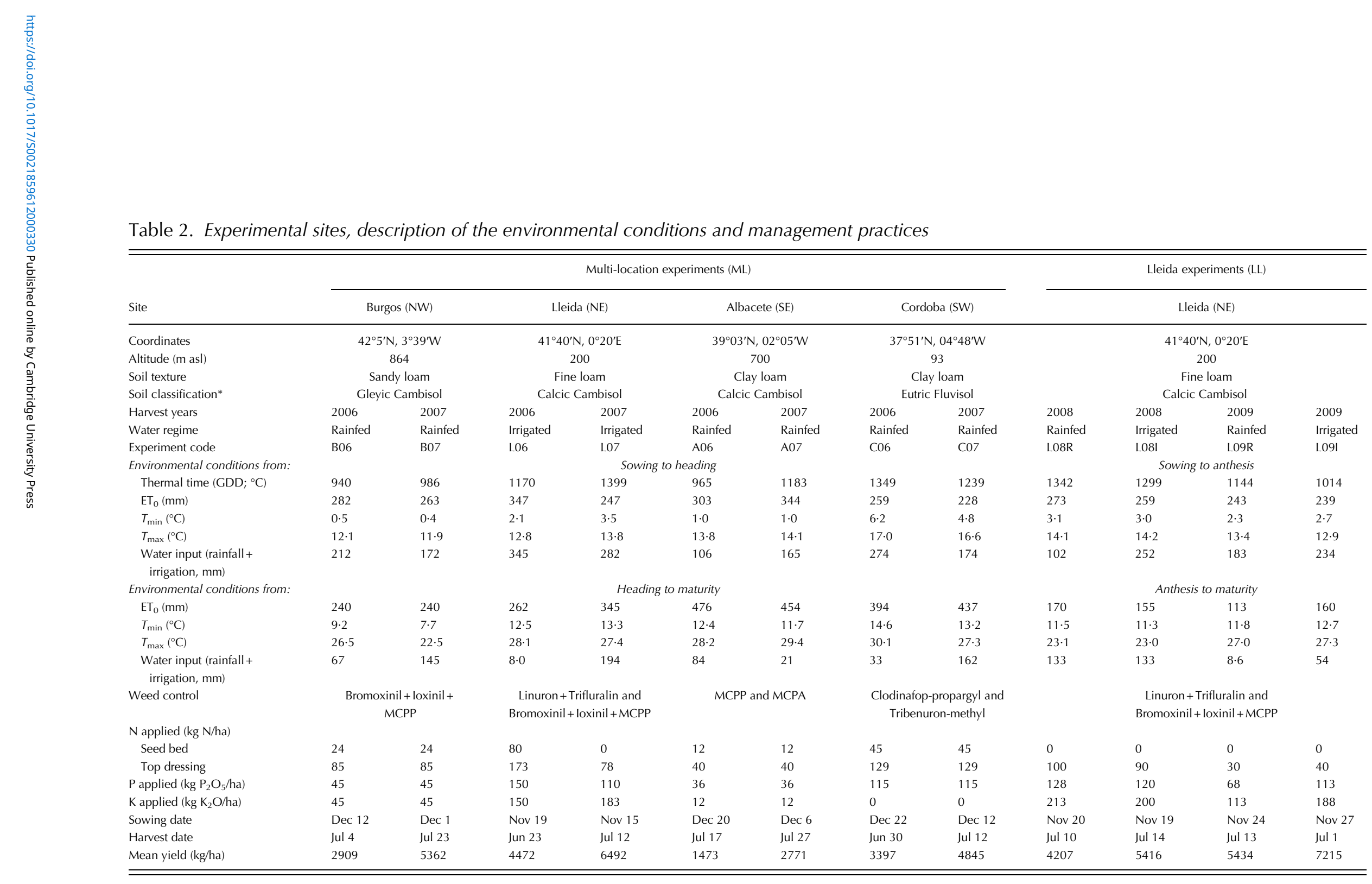

Table 2. Experimental sites, description of the environmental conditions and management practices

$T_{\min }$ and $T_{\max }$ are average minimum and maximum daily temperatures, respectively.

$\mathrm{ET}_{0}$ is the reference evapotranspiration computed by the Penman-FAO methodology (Allen et al. 1998).

* Soil-type classification according to FAO (1998). 
Yield components (number of spikes $/ \mathrm{m}^{2}$, number of grains/spike and mean grain weight (MGW)) and the number of plants $/ \mathrm{m}^{2}$ and stems/plant in Lleida experiments, were determined from the whole plants pulled up from a $1 \mathrm{~m}$ long sample taken from a central row of each plot before harvesting.

In the experiments conducted in Lleida in 2008 and 2009, 10 plants were randomly selected from the sample in the laboratory for further determinations. Plant height was measured in 10 main tillers from the tillering node to the top of the spike excluding the awns, number of spikelets/spike, number of grains/ spikelet and spike length were assessed for main stems and tillers separately. Spikes and grains were weighed after being oven-dried at $70^{\circ} \mathrm{C}$ for $48 \mathrm{~h}$. The rest of the sample was used to determine the total number of stems/plant and the proportion of them bearing spikes (fertile tillering) and, after drying, aboveground biomass and grain weight, which were used to calculate $\mathrm{HI}$.

\section{Statistical analysis}

Combined ANOVA were performed for all the studied traits. In the model used for the ANOVA of multi-location experiments (2006 and 2007), the genotype effect was partitioned into breeding period considered as a fixed effect and genotype within breeding period considered as a random effect. All analyses were carried out with the SAS-STAT (SAS Institute Inc. 2009) and GENSTAT (Payne et al. 2006) statistical packages.

Absolute genetic gain (AGG) and relative genetic gain (RGG) during the 20th century were computed as the slope of the linear regression between the absolute or relative value of the trait and the year of genotype release. Relative values were computed for each genotype as a percentage with regard to the average value of all genotypes.

Stepwise regression analysis was conducted with the RGG for yield in each experiment as the dependent variable and the climatic features depicted in Table 2 as the independent variables. Regression models (linear or bilinear when appropriate, $Y=B X+A$ $(X<1>C)+B C \quad(X<1>C)$, with the slope of the second segment equal to zero) were also fitted to the relationships between variables and those between variables and the year of release of the genotypes, using the Tablecurve 2D v2.03 software (Jandel 1991).

\section{RESULTS}

Yield and yield components

The combined ANOVA of yield data from multilocation experiments revealed a significant effect of most factors (data not shown). The mean yield of the experiments ranged from $1473 \mathrm{~kg} / \mathrm{ha}$ in Albacete in 2006 (A06) to $6492 \mathrm{~kg} / \mathrm{ha}$ in Lleida in 2007 (L07, Table 2). When the whole set of experiments was considered together, yield was estimated to increase significantly at a rate of $35 \cdot 1 \mathrm{~kg} / \mathrm{ha} / \mathrm{yr}$, which represents an RGG of $0 \cdot 88 \% / y r$ (Table 3, Fig. 1), whereas the regression equation fitted to the relationship between year of release and yield for intermediate and modern genotypes was not significant (Fig. 1). Given the statistical significance of the site $\times$ year $\times$ genotype (breeding period) interaction, genetic gains in yield and yield components were computed for each experiment. The results indicated great variability between experiments, with AGG for yield ranging from $7.7 \mathrm{~kg} / \mathrm{ha} / \mathrm{yr}$ in A06 to $66.5 \mathrm{~kg} / \mathrm{ha} / \mathrm{yr}$ in C07, and RGG ranging from 0.37 in B07 to $1.59 \% / y r$ in $\mathrm{C} 06$ (Table 3). The coefficient of determination of the relationship between the mean yield of each experiment and the estimated AGG was $R^{2}=0 \cdot 37$ $(P=0 \cdot 106)$, and that of the relationship between the mean yield of each experiment and the RGG was $R^{2}=0.02 \quad(P=0.738)$. The average daily minimum temperature from sowing to heading was the only variable entered in the stepwise regression model built to explain variations in yield RGG using climatic features as independent variables (Fig. 2).

The number of grains/spike and, to a lesser extent, the number of spikes $/ \mathrm{m}^{2}$ were the yield components most affected by breeding activities during the 20th century, as they increased at a relative rate of $0.60 \% / \mathrm{yr}$ and $0 \cdot 30 \% / y r$, respectively, while no significant changes were observed for MGW when data were averaged across experiments (Table 3). However, the estimated genetic gains for yield components also differed greatly between experiments. The number of spikes $/ \mathrm{m}^{2}$ showed significant increases in B06, L06, and C06, while no significant changes were detected in the remaining experiments. Similarly to the findings for yield, increases in the number of grains/spike were significant in all the experiments, with RGG ranging from $0.37 \% / y r$ in B07 to $1.08 \% / y r$ in C07. Changes in MGW were only significant in three experiments, with RGG ranging from $-0 \cdot 22$ to $-0 \cdot 40 \% / y r$ (Table 3 ). Although the genetic gains for yield and yield components depended on the experiment, differences 


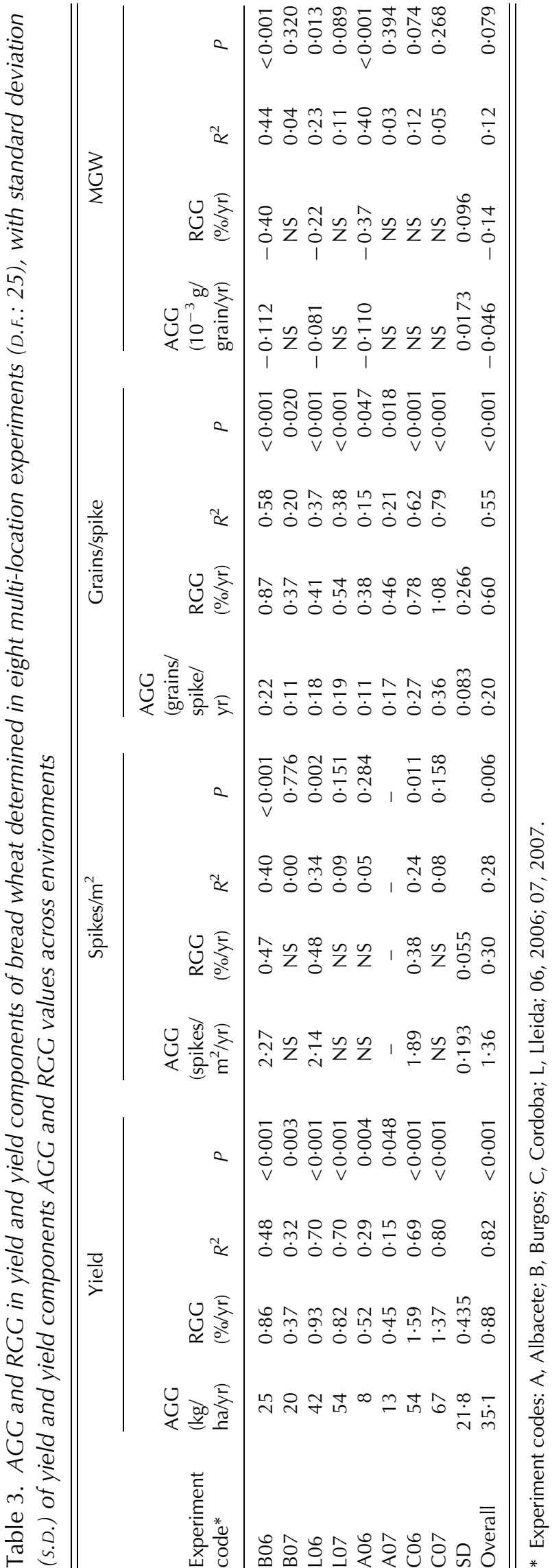

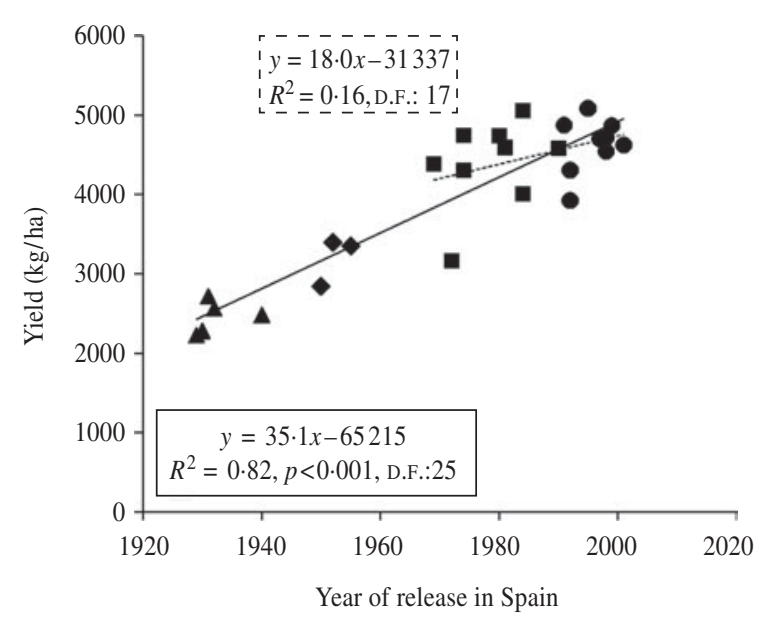

Fig. 1. AGGs in grain yield of 26 bread wheat genotypes released in Spain during the 20th century. Each point was obtained by averaging data of eight environments and three blocks per environment. Breeding periods are identified with triangles for local landraces, diamonds for initial cultivars, squares for intermediate cultivars and circles for modern cultivars. The broken line indicates the gain between intermediate and modern cultivars.

between experiments were of a quantitative nature because all significant rates of change were positive for spikes $/ \mathrm{m}^{2}$ and grains/spike, but negative for MGW. None of the climatic features considered contributed significantly to explaining genetic changes in yield components.

The results showed that differences between breeding periods were significant for yield, grains/spike and MGW, but not for number of spikes $/ \mathrm{m}^{2}$ (data not shown). The breeding period was the factor that explained the largest proportion of variability for grains/ spike (data not shown).

Grain yield during the 20th century increased by $88 \%$, but the largest rises occurred before the end of the intermediate period, since no significant differences in yield and yield components appeared between intermediate and modern cultivars (Table 4). The initial cultivars out-yielded the local landraces by $30 \%$, while an additional yield increase of $37 \%$ was attained by the intermediate cultivars. Yield gains were due to increases of $20 \%$ in the number of spikes $/ \mathrm{m}^{2}$ and of $65 \%$ in the number of grains/spike, but a reduction of $10 \%$ in MGW. The improved yield of initial cultivars in comparison with the landraces was due to their greater number of grains/spike (which increased by $58 \%$ ), despite the fact that the number of spikes $/ \mathrm{m}^{2}$ was similar and MGW was $16 \%$ lower (Table 4). Changes in yield components between 
Table 4. Mean values of yield and yield components for 26 bread wheat genotypes released in different periods in Spain and grown in eight multi-location experiments. Numbers in parentheses indicate the percentage of change with respect to the previous period. The standard error of the differences (S.E.D.) of the means of yield and yield components are presented

\begin{tabular}{llllll}
\hline \hline Breeding period & D.F. & Yield $(\mathrm{kg} / \mathrm{ha})$ & Spikes/m ${ }^{2 *}$ & Grains/spike & MGW $\left(10^{-3} \mathrm{~g}\right)$ \\
\hline Landraces & 4 & 2457 & 401 & $22 \cdot 3$ & $36 \cdot 7$ \\
Initial & 2 & $3198(30)$ & $432(7 \cdot 7)$ & $35 \cdot 2(58)$ & $30 \cdot 7(-16)$ \\
Intermediate & 8 & $4397(37)$ & $459(6 \cdot 2)$ & $36 \cdot 8(4 \cdot 5)$ & $33 \cdot 4(8 \cdot 8)$ \\
Modern & 8 & $4628(5 \cdot 2)$ & $483(5 \cdot 2)$ & $36 \cdot 7(-0 \cdot 3)$ & $33 \cdot 0(-1 \cdot 2)$ \\
S.E.D. & 274 & $39 \cdot 5$ & $2 \cdot 45$ & $1 \cdot 92$ \\
\hline \hline
\end{tabular}

* The number of spikes $/ \mathrm{m}^{2}$ could not be determined in A07.

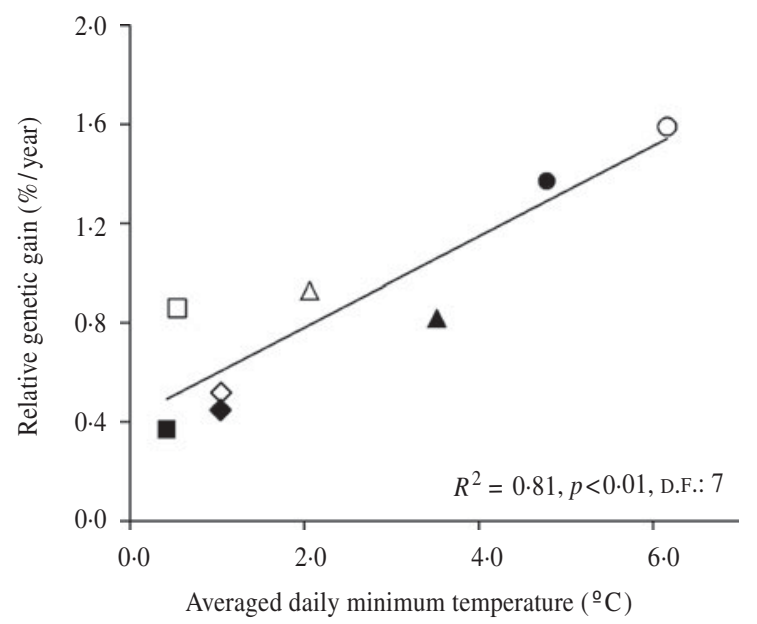

Fig. 2. Relationship between the RGG for yield and the average daily minimum temperatures from sowing to heading. Each point corresponds to one of eight experiments identified as follows: squares, Burgos; diamonds, Albacete; triangles, Lleida and circles, Cordoba. Open and solid symbols correspond to experiments conducted in 2006 and 2007, respectively.

initial and intermediate cultivars ranged from $4.5 \%$ for grains/spike to $8 \cdot 8 \%$ for MGW, but none of them were significant.

Biomass and its partitioning

Data from four experiments conducted in Lleida during 2 years under two water regimes (L08R, L08I, L09R and L09I) with a subset of 16 representative genotypes were used to assess the changes caused by breeding on biomass production and allocation. The results indicate that yield gains were due to increases in $\mathrm{HI}$, with aboveground biomass being unchanged (Fig. 3a-d). $\mathrm{HI}$ increased from $0 \cdot 24$ for the landrace Aragon 03 to 0.48 for the newest cultivar, Califa Sur. However, improvements in $\mathrm{HI}$ were not linear across the century, as a plateau in $\mathrm{HI}$ was reached after 1961 (Fig. 3b). Although no significant relationship was found between yield or year of release and biomass when the 16 genotypes were considered together, positive and significant relationships between biomass and yield and between biomass and year of genotype release appeared when landraces were removed from the analyses (broken lines in Fig. 3c, d). Crop biomass increased significantly and linearly from initial cultivars to modern ones, but the great variability within periods for this trait prevented differences between breeding periods from being significant in the ANOVA (data not shown).

The average number of plants $/ \mathrm{m}^{2}$ at maturity was 380 in 2008 and 416 in 2009, without significant differences between genotypes (data not shown). The introduction of initial cultivars reduced the number of stems/plant at maturity (Fig. 3f), but caused a rise in the proportion of stems bearing spikes (Fig. $3 g, h$ ), which thereafter remained unchanged. Initial cultivars were also a first step in the reduction of plant height, which decreased steadily until the end of the century (Fig. $3 i, j$ ). The increase in fertile tillering was associated with increases in $\mathrm{HI}$ of up to 0.32 (Fig. 4a), and with a decrease in the total number of stems/plant that started with the introduction of the first improved cultivars (Fig. 4C). In addition, increases in $\mathrm{HI}$ beyond 0.36 were associated with a reduction in plant height that started with the release of initial cultivars (Fig. 4b).

\section{Spike components}

The contribution of the main and secondary spikes to yield improvement during the 20th century was investigated in the experiments conducted in Lleida in 2008 and 2009 with 16 genotypes. The weight at ripening of main and secondary spikes increased 

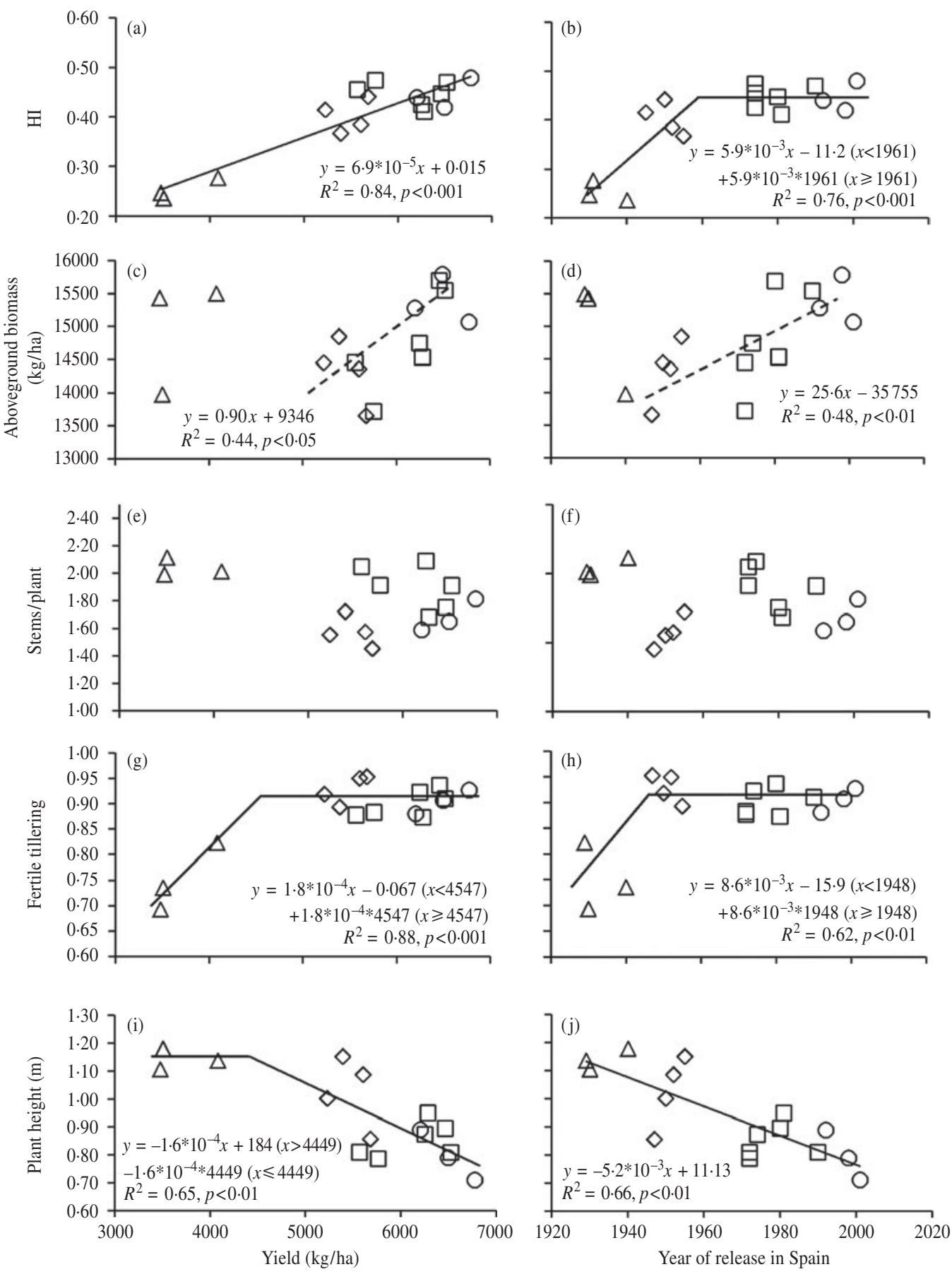

Fig. 3. Relationship between $\mathrm{HI}$, aboveground biomass, fertile tillering, number of stems/plant at maturity and plant height and both yield and year of release of 16 bread wheat genotypes widely grown in Spain during the 20th century. Each point represents the mean value of one genotype across four experiments. Breeding periods are identified with triangles for local landraces, diamonds for initial cultivars, squares for intermediate cultivars and circles for modern cultivars. Broken lines indicate relationships without considering local landraces (D.F.: 15).

significantly during the last century, with RGG of $0.57 \% / y r$ and $0.75 \% / y r$, respectively (Fig. $5 a$ ). These increases were mainly based on a boost in the number of grains/spike, which accounted for RGG of $0.58 \% / y r$ and $0 \cdot 70 \% / y r$ in main and secondary spikes, respectively (Fig. 5b), while no significant changes in MGW were observed (Fig. 5c). From a breeding historical perspective, the largest gain in spike weight occurred with the introduction of initial cultivars, which caused an increase of $31 \%$ in main spike weight 

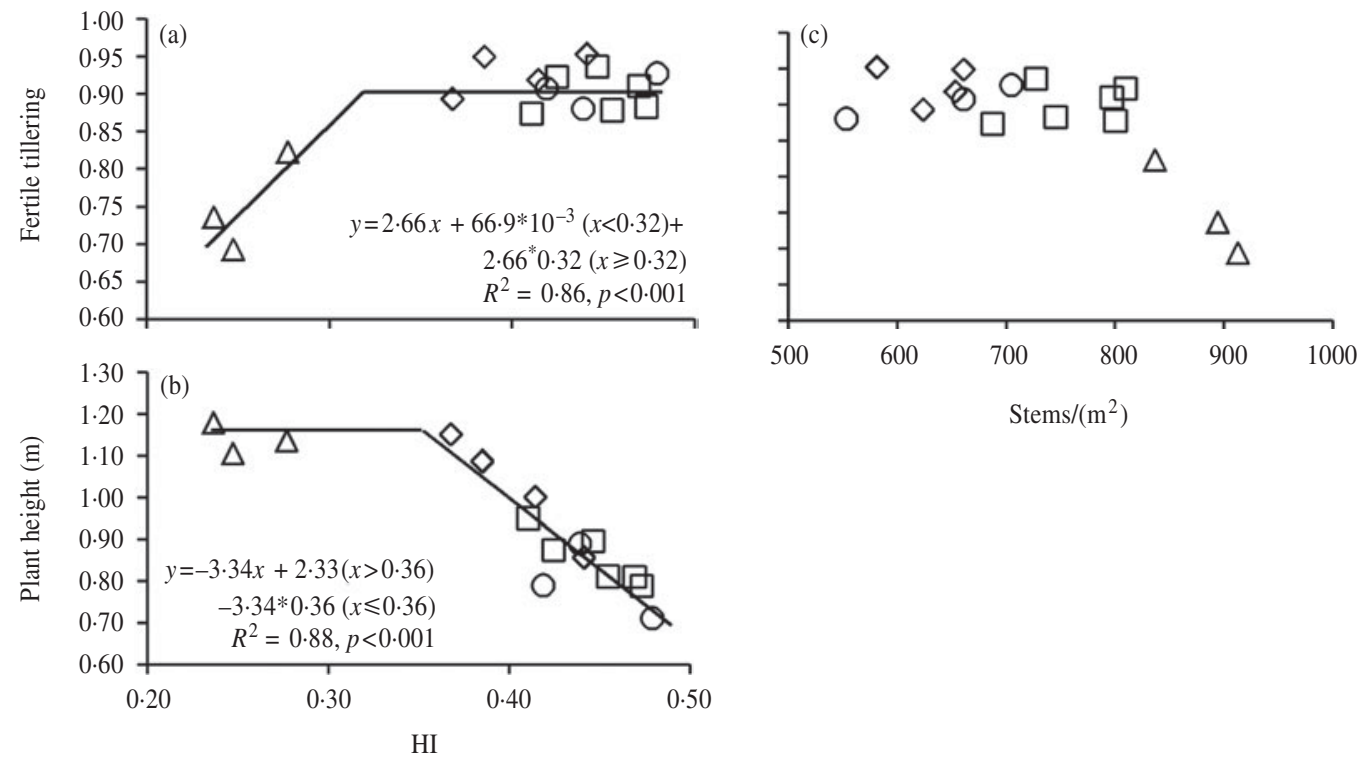

Fig. 4. Relationships between (a) $\mathrm{HI}$ and fertile tillering, (b) $\mathrm{HI}$ and plant height, and (c) fertile tillering and number of stems $/ \mathrm{m}^{2}$, of 16 bread wheat genotypes widely grown in Spain during the 20th century. Each point represents the mean value of one genotype across four experiments. Breeding periods are identified with triangles for local landraces, diamonds for initial cultivars, squares for intermediate cultivars and circles for modern cultivars. Equations and $R^{2}$ values are only presented for significant relationships at $P<0 \cdot 05$ (D.F.: 15).
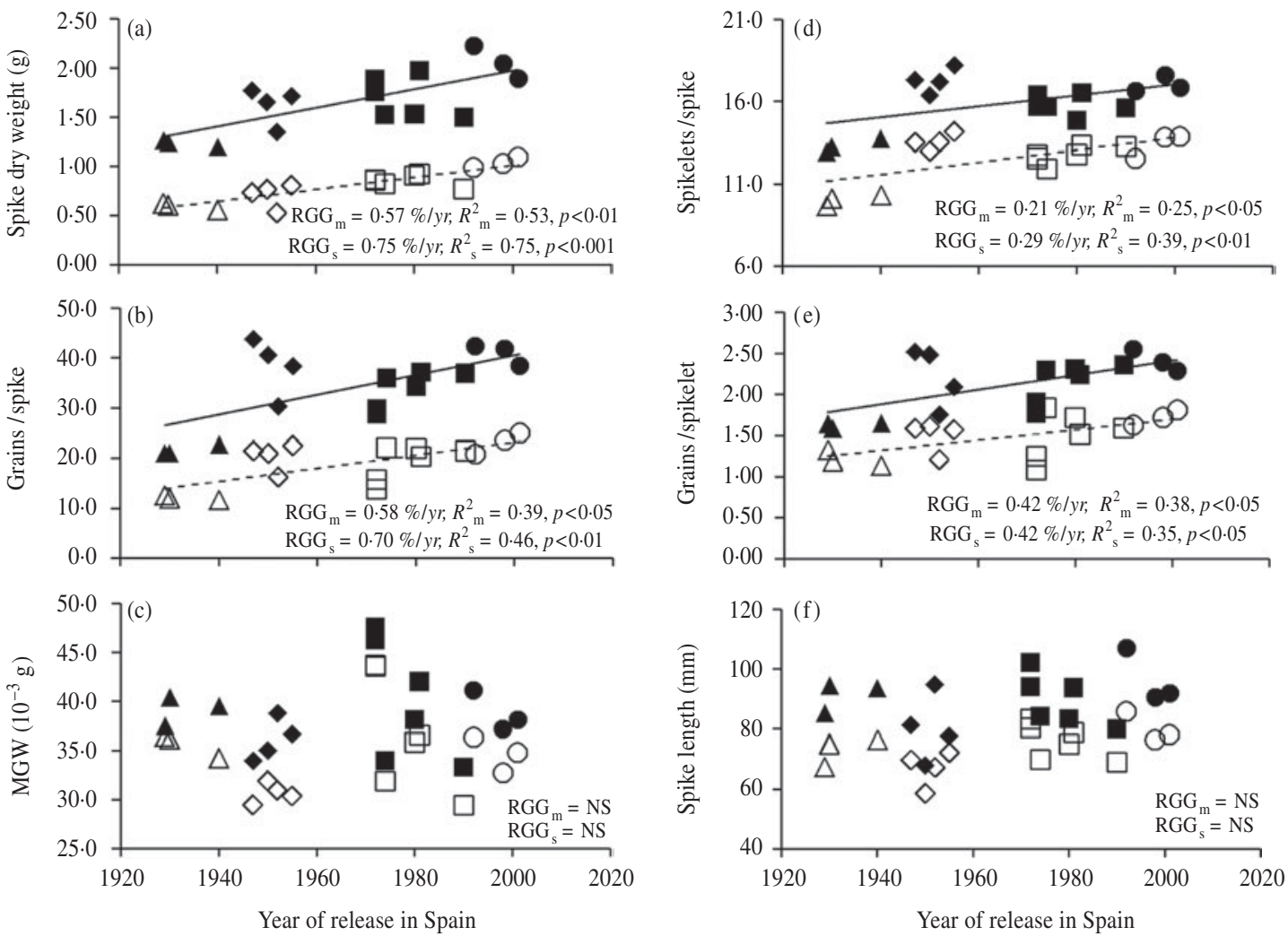

Fig. 5. Relationships between main spike (m, closed symbols) and secondary spike (s, open symbols) components and year of release of 16 bread wheat genotypes widely grown in Spain during the 20th century. Each point represents the mean value of one genotype across four experiments. Breeding periods are identified with triangles for local landraces, diamonds for initial cultivars, squares for intermediate cultivars and circles for modern cultivars (D.F.: 15). RGG= relative genetic gain. 
and an increase of $77 \%$ in the number of grains/spike. The rise in the weight of secondary spikes was evenly distributed during the century.

The increases in the number of grains/spike were due to improvements in both the number of spikelets/ spike, which increased at a rate of $0 \cdot 21 \% / \mathrm{yr}$ and $0 \cdot 29 \% / y r$ on main stem and tillers, respectively (Fig. $5 d$ ), and the number of grains/spikelet, which increased at a rate of $0 \cdot 42 \% / y r$ in both types of spike (Fig. 5e). Genetic gains in the number of grains of main spikes contributed by initial cultivars were related to the improvement of both the number of spikelets/spike, which increased by $29 \%$, and the number of grains/ spikelet, which rose significantly, by c. $37 \%$.

No changes in spike length were recorded (Fig. $5 f$ ). The slopes of the linear models fitted for each spike component were compared between main and secondary stems, but no significant differences between them were found (data not shown).

\section{DISCUSSION}

The evaluation of historical series of genotypes is a common approach used in several countries to quantify the achievements of past breeding efforts (Austin et al. 1989; Perry \& D’Antuono 1989; Donmez et al. 2001; Morgounov et al. 2010). The present study examined a set of 26 bread wheat genotypes widely grown in Spain in different periods during the 20th century, in order to estimate the genetic gain in yield and to understand its causes through the identification of crop traits associated with yield improvements. The AGG for yield was $35 \cdot 1 \mathrm{~kg} / \mathrm{ha} / \mathrm{yr}$, which equated to an RGG of $0 \cdot 88 \% / y$ r. These results are comparable or slightly higher than those reported by previous studies conducted with bread wheat in other countries and with durum wheat in Spain (Royo et al. 2008). RGG for yield has been reported to be of $0.51 \% / y r$ in the UK from 1900 to 1985 (Austin et al. 1989), 0.66\%/yr in France from 1962 to 1988 (Brancourt-Hulmel et al. 2003), $0 \cdot 68 \% / y r$ in the United States (Cox et al. 1988) and $0.70 \% / y r$ in Siberia (Morgounov et al. 2010). The fact that some of the genotypes most widely grown in Spain during the last century were derived from CIMMYT germplasm may explain the coincidence between the yield RGG estimated in the present study and the $0 \cdot 88 \% / y r$ reported by CIMMYT for the period 1962-88 (Sayre 1996).

When RGG for yield was calculated for each of the eight environments in which field experiments were conducted, the range of variation was greater than $400 \%$, suggesting a very high dependence of the estimated genetic gains on the environmental conditions. Previous studies have attributed these dissimilarities to the different yield potential of the environments (Brancourt-Hulmel et al. 2003), to factors affecting old and modern genotypes in an opposite way, such as the incidence of host-specific pathogens (Cox et al. 1988), and to the environmental characteristics that induce genotype $\times$ environment interactions (GEI). GEI is a main constraint in assessing genetic gains, especially in countries with great environmental variations and large yield fluctuations between years, as is typical in Mediterranean environments. The bias created by the assessment of yield gains in only one environment was overcome in the present study by conducting experiments under a wide range of environmental conditions involving the main wheat-growing areas of Spain. In the present study, the differences between the mean yield of the eight environments explained 0.37 of the variations in yield AGG. Although this value was not significant, probably due to the limited number of environments involved in the present study, it accounted for a considerable proportion of the observed variability, thus showing a tendency of the mean yield of the environment to partially explain differences in the estimated AGG in yield.

In contrast, variations in yield RGG across environments were largely explained by the average minimum daily temperatures from sowing to heading $(0 \cdot 81$ of the total RGG variance). The lowest RGG were recorded in the environments with the lowest minimum temperatures before heading independently of the mean yield of the environment, indicating that the yield differences between landraces and improved cultivars increased as the minimum daily temperatures before heading increased. In view of the results of a previous study conducted with the same set of genotypes (Sanchez-Garcia et al. 2012), this result may be interpreted in adaptation terms as: (i) the specific adaptation of Spanish landraces to cold environments, (ii) the wider adaptation of modern cultivars in comparison with local landraces and (iii) the good performance of modern spring genotypes in warm Spanish environments. Average minimum daily temperature has been reported to be a major factor for wheat yield formation under Mediterranean conditions (Siddique et al. 1990; Le Houerou 2004) and is among the main variables determining GEI on yield in Spain (Voltas et al. 2005; Sanchez-Garcia 
et al. 2012). The importance of temperature before heading in adaptation of wheat to Mediterranean conditions has also been demonstrated in durum wheat (Royo et al. 2010).

Of the three main yield components, the number of grains/spike was the one most related to wheat breeding achievements, as it explained up to 0.67 of yield increases in Spain during the last century, the remaining 0.33 being explained by the number of spikes $/ \mathrm{m}^{2}$, while no consistent changes were observed in MGW. The relationship between the number of grains/spike and genetic gains in yield is universally accepted in bread and durum wheat, as it has been identified in many studies involving a wide range of environmental conditions (Waddington et al. 1986; Austin et al. 1989; Perry \& D'Antuono 1989; Canevara et al. 1994; Donmez et al. 2001; Royo et al. 2007). In the present study, increases in yield and number of grains/spike were significant in all the environments, while increases in number of spikes $/ \mathrm{m}^{2}$ were not consistent in all of them. This could be associated with the larger GEI component of the variance recorded for number of spikes $/ \mathrm{m}^{2} \quad(0.28$ of total variation) in comparison with yield $(0 \cdot 14)$ and number of grains/ spike $(0 \cdot 18)$. The non-significant differences between breeding periods in the number of spikes $/ \mathrm{m}^{2}$ could also be related to the data missing in one of the experiments. Moreover, increases in the number of spikes $/ \mathrm{m}^{2}$ were only significant in three environments characterized by dry and warm grain-filling periods, which probably caused a reduction in the tiller survival in the landraces, the latest-heading genotypes (Sanchez-Garcia et al. 2012), which increased the differences in spikes $/ \mathrm{m}^{2}$ between landraces and improved cultivars. The great environmental effects on the number of spikes $/ \mathrm{m}^{2}$ found in the present study are consistent with the variability of results of previous studies evaluating genetic changes in spikes/ $\mathrm{m}^{2}$ over time, which range from a steady amount (Waddington et al. 1986; Calderini et al. 1995) to large increases (Austin et al. 1989; Donmez et al. 2001; Shearman et al. 2005), with slight improvements also being reported from experiments conducted under Mediterranean conditions (Perry \& D'Antuono 1989; Canevara et al. 1994; Royo et al. 2007).

The classification of genotypes into historical breeding periods made it possible to identify two main episodes contributing to genetic improvements in yield in Spain during the last century. The first one, which caused a yield increase of $30 \%$, was the transition from traditional landraces to the first cultivars released from the earliest Spanish breeding programmes and the improved cultivars introduced in Spain from foreign countries, mainly Italy and France during the 1950s. The increase estimated for this period matches with the improvement that occurred in 1956 in the wheat yield of Spanish farms (Calderini \& Slafer 1998). The reduction in plant height during this period was accompanied by an increase in the proportion of tillers bearing spikes and a huge rise in HI. The yield rise derived from the introduction of initial cultivars was partially caused by an improvement of c. 58\% in the number of grains/spike despite a reduction in grain weight of c. $16 \%$ in comparison with local landraces. Three of the four initial cultivars included in the present study (Estrella, originally named Etoile-de-Choisy, Impeto and Mara) carry the Rht8c dwarfing gene and probably the photoperiodinsensitive gene PpD1 (Worland et al. 1998), which have been reported to reduce plant height, enhance spike fertility, and consequently improve grain yield (Borojevic \& Borojevic 2005). The present results indicate that the great increase in the grain number of initial cultivars was sufficient to compensate for the reduction in grain weight, thus resulting in higher yields. These results evidence the success of the work conducted by wheat breeding pioneers, such as Nazareno Strampelli in Italy (Salvi et al. 2012) and Josep Pané in Spain.

A second relevant breeding episode occurred with the introduction, in the late 1960s, of cultivars derived from CIMMYT semi-dwarf germplasm, such as the widely grown cvars Siete Cerros, Yecora, Cajeme, Anza and Cartaya, and of European cultivars of winter growth-habit, such as the French cvars Marius and Soissons. This new germplasm further reduced plant height and increased the number of tillers/plant while maintaining their rate of fertility. This transition brought a yield increase of $37 \%$ in comparison with the initial cultivars, but it was due to slight increases in all three main yield components rather than significant rises in any of them. The wide adaptation of foreign cultivars released during this period (Sanchez-Garcia et al. 2012) may partially explain their great success in terms of both productivity and adoption by farmers. The evidence of a non-significant yield increase during the period 1970-2000 suggests that a plateau was reached for yield gains in Spain during the last 30 years of the century, agreeing with the results reported for other countries where slight or non-significant yield increases were observed (Sener et al. 2009; Fischer \& Edmeades 2010). 
One of the physiological approaches used to understand yield formation consists of considering yield as a function of the biomass per unit area at maturity and the $\mathrm{HI}$ or proportion of the aboveground biomass partitioned to grain (yield=aboveground biomass $\times \mathrm{HI}$ ). The introduction of initial cultivars during the 1950s did not significantly modify the crop biomass, but caused a $60 \%$ increase in $\mathrm{HI}$, which rose from $0 \cdot 25$ to $0 \cdot 40$. The huge improvement in $\mathrm{HI}$ in this first stage could be associated with three factors: (i) a reduction in plant height of c. $10 \%$, very probably due to the presence in initial cultivars of Rht8c and $P p D 1$ genes, (ii) a $28 \%$ decrease in the number of stems/plant and (iii) an increase from 0.75 to 0.93 in the proportion of stems bearing spikes. Tillering reduction has been described as an advantageous trait under terminal drought stress, as it diminishes soil water use prior to anthesis (Richards 1988; Duggan et al. 2005). A decrease in plant height and the number of stems/plant and an increase in the proportion of them bearing spikes probably reduced competition between the growing spikes and the growing stems, enhancing the partitioning of assimilates to the spike (Fischer \& Stockman 1986) and thus resulting in an increase in the weight of main spikes. Improvements in the number of spikelets/spike and in grain setting were not accompanied by an enlargement of the spikes, so spike compactness augmented. Increases in spike fertility and decreases in grain weight have been reported to be pleiotropic effects of the Rht8c dwarfing gene and the photoperiod insensitive gene $P p D 1$ (Canevara et al. 1994; Borojevic \& Borojevic 2005). The efforts made by local breeders during the early decades of the 20th century to increase grain setting probably improved the adaptation of wheat to Mediterranean environments, where abiotic stresses during grain filling are the main cause of floret abortion (Álvaro et al. 2008b).

The introduction of intermediate cultivars caused a slight, not significant, increase in aboveground biomass, but caused a second, smaller rise in $\mathrm{HI}$, which reached values of c. 0.45 that were not further improved by the cultivars released during the 1990s. Rises in $\mathrm{HI}$ during this phase could be explained by a further reduction of $17 \%$ in plant height and increases of c. $55 \%$ in the number of tillers/plant, while their rate of fertility was maintained. Given the limited scope for raising $\mathrm{HI}$ beyond $0 \cdot 50$ (Fischer \& Edmeades 2010), further yield improvements must rely on biomass production, as was reported for the cultivars released in the UK between 1983 and 1995 (Shearman et al.
2005). However, this does not seem to be the case in Spain, where neither the yield changes nor the $4.0 \%$ increase in biomass during the last decade of the century were significant.

The great differences induced by the environment in the rates of genetic gain found in the present study may have important implications in the current scenario of global climate change. The $1.8^{\circ} \mathrm{C}$ rise in average global temperature predicted for 2050 (Meehl et al. 2007) will force farmers to grow genotypes which are more tolerant, among other factors, to high temperatures (Ceccarelli et al. 2010; Peltonen-Sainio et al. 2011). The large effect of the climatic variables, particularly temperature, over the estimated genetic gains of the present study emphasizes the role played by adaptation mechanisms over past breeding achievements, and the need to continue their improvement to face future environmental changes. The highest genetic yield gains observed in environments with greater minimum temperatures before heading suggest that the genotypes released recently in Spain are better adapted than the old ones to high temperatures. Therefore, the adaptation trends related to breeding progress in Spain during the last century appear to be in the right direction to meet the expected temperature increases.

This study was partially funded by INIA under projects RTA2004-058-C04 and RTA2009-061-C03 and by CICYT, under project AGL-2009-11187. The contribution to field experiments by Dr Josefina C. Sillero, from IFAPA and Mr Juan Escribano from ITAP, is fully acknowledged. M. Sanchez-Garcia was a recipient of a $\mathrm{PhD}$ grant from INIA.

\section{REFERENCES}

Allen, R. G., Pereira, L. S., Raes, D. \& Smith, M. (1998). Crop Evapotranspiration. Guidelines for Computing Crop Water Requirements. Irrigation and Drainage Paper 56. Rome: FAO.

Álvaro, F., Isidro, J., Villegas, D., García Del Moral, L. F. \& Roro, C. (2008a). Old and modern durum wheat varieties from Italy and Spain differ in main spike components. Field Crops Research 106, 86-93.

Álvaro, F., Royo, C., García Del Moral, L. F. \& Villegas, D. (2008b). Grain filling and dry matter translocation responses to source-sink modifications in a historical series of durum wheat. Crop Science 48, 1523-1531.

Austin, R. B., Bingham, J., Blackwell, R. D., Evans, L. T., Ford, M. A., Morgan, C. L. \& TAYlor, M. (1980). Genetic improvements in winter wheat yields since 1900 and 
associated physiological changes. Journal of Agricultural Science, Cambridge 94, 675-689.

Austin, R. B., Ford, M. A. \& Morgan, C. L. (1989). Genetic improvement in the yield of winter wheat: a further evaluation. Journal of Agricultural Science, Cambridge 112, 295-301.

BOROJEVIC, K. \& BoroJEVIC, K. (2005). Historic role of the wheat variety Akakomugi in southern and central European wheat breeding programs. Breeding Science 55, 253-256.

Brancourt-Hulmel, M., Doussinault, G., Lecomte, C., Berard, P., Le Buanec, B. \& Trottet, M. (2003). Genetic improvement of agronomic traits of winter wheat cultivars released in France from 1946 to 1992. Crop Science 43, 37-45.

Calderini, D. F. \& Slafer, G. A. (1998). Changes in yield and yield stability in wheat during the 20th century. Field Crops Research 57, 335-347.

Calderini, D. F., Dreccer, M. F. \& Slafer, G. A. (1995). Genetic improvement in wheat yield and associated traits. A reexamination of previous results and the latest trends. Plant Breeding 114, 108-112.

Canevara, M. G., Romani, M., Corbellini, M., Perenzin, M. \& BORGHI, B. (1994). Evolutionary trends in morphological, physiological, agronomical and qualitative traits of Triticum aestivum L. cultivars bred in Italy since 1900. European Journal of Agronomy 3, 175-185.

Ceccarelli, S., Grando, S., Maatougui, M., Michael, M., Slash, M., Haghparast, R., Rahmanian, M., Taheri, A., AlYassin, A., Benbelkacem, A., LabDi, M., Mimoun, H. \& NACHIT, M. (2010). Plant breeding and climate changes. Journal of Agricultural Science, Cambridge 148, 627-637.

Cox, T.S., Shroyer, J.P., Ben-Hul, L., Sears, R. G. \& MARTIN, T.J. (1988). Genetic improvement in agronomic traits of hard red winter wheat cultivars from 1919 to 1987. Crop Science 28, 756-760.

Donmez, E., Sears, R. G., Shroyer, J.P. \& Paulsen, G. M. (2001). Genetic gain in yield attributes of winter wheat in the Great Plains. Crop Science 41, 1412-1419.

Duggan, B. L., Richards, R. A. \& Van Herwaarden, A. F. (2005). Agronomic evaluation of a tiller inhibition gene (tin) in wheat. II. Growth and partitioning of assimilate. Australian Journal of Agricultural Research 56, 179-186.

EUROSTAT (2011). Agriculture. Brussels: European Commission. Available online at: http://epp.eurostat.ec. europa.eu/portal/page/portal/agriculture/data/database (verified 23 Feb 2012).

FAO (1998). World Reference Base for Soil Research 1998. World Soil Resources Report vol. 84. Rome: FAO.

Fischer, R. A. \& EdmeAdes, G. O. (2010). Breeding and cereal yield progress. Crop Science 50, 85-98.

FisCHER, R. A. \& StOCKMAN, Y. M. (1986). Increased kernel number in Norin 10-derived dwarf wheat. Evaluation of the cause. Australian Journal of Plant Physiology 13, 767-784.

JANDEL SCIENTIFIC (1991). TableCurve 2D Windows v.2.0 User's Manual. San Rafael, CA: Jandel Scientific.

Le Houerou, H. N. (2004). An agro-bioclimatic classification of arid and semiarid lands in the isoclimatic Mediterranean zones. Arid Land Research and Management 18, 301-346.
Martos, V., Royo, C., Rharrabti, Y. \& Garcia Del Moral, L. F. (2005). Using AFLPs to determine phylogenetic relationships and genetic erosion in durum wheat cultivars released in Italy and Spain throughout the 20th century. Field Crops Research 91, 107-116.

Meehl, G. A., Stocker, T. F., Collins, W. D., Friedlingstein, P., Gaye, A. T., Gregory, J.M., Kitoh, A., KnUttl, R., Murphy, J. M., Noda, A., Raper, S. C. B., Watterson, I. G., Weaver, A.J. \& ZhaO, Z.C. (2007). Global climate projections. In Climate Change 2007: the Physical Science Basis. Contribution of the Working Group I to the Fourth Assessment Report of the Intergovernmental Panel on Climate Change (Eds S. Solomon, D. Qin, M. Manning, Z. Chen, M. Marquis, K. B. Averyt, M. Tignor \& H. L. Miller), pp. 749-845. Cambridge, UK: Cambridge University Press.

Morgounov, A., Zykin, V., Belan, I., Roseeva, L., Zelenskiy, Y., Gomez-Becerra, H. F., Budak, H. \& Bekes, F. (2010). Genetic gains for grain yield in high latitude spring wheat grown in Western Siberia in 1900-2008. Field Crops Research 117, 101-112.

Payne, R. W., Harding, S. A., Murray, D. A., Soutar, D. M., Baird, D. B., Welham, S. J., Kane, A. F., Gilmour, A. R., Thompson, R., Webster, R. \& TunNicliffe Wilson, G. (2006). GenStat Release 9 Reference Manual. Part 2: Directives. Hemel Hempstead, UK: VSN International.

Peltonen-Sainio, P., Jauhiainen, L. \& Hakala, K. (2011). Crop responses to temperature and precipitation according to long-term multi-location trials at high-latitude conditions. Journal of Agricultural Science, Cambridge 149, 49-62.

Perry, M. W. \& D'Antuono, M. F. (1989). Yield improvement and associated characteristics of some Australian spring wheat cultivars introduced between 1860 and 1982 . Australian Journal of Agricultural Research 40, 457-472.

Pfeiffer, W. H., Sayre, K. D. \& Reynolds, M. P. (2000). Enhancing genetic grain yield potential and yield stability in durum wheat. In Durum Wheat Improvement in the Mediterranean Region: New Challenges (Eds C. Royo, M. M. Nachit, N. Di Fonzo \& J. L. Araus), pp. 83-94. Zaragoza, Spain: Óptions Mediterranéenes, CIHEAM.

RICHARDS, R. A. (1988). Tiller inhibitor gene in wheat and its effect on plant growth. Australian Journal of Agricultural Research 39, 749-757.

Royo, C. \& BRICEÑo-FÉlIX, G. A. (2011). Spanish wheat pool. In The World Wheat Book: a History of Wheat Breeding, Volume 2 (Eds A.P. Bonjean, W. J. Angus \& M. Van Ginkel), pp. 121-154. Paris: Lavoisier Publishing Inc.

Royo, C., Álvaro, F., Martos, V., Ramdani, A., Isidro, J., Villegas, D. \& García Del Moral, L. F. (2007). Genetic changes in durum wheat yield components and associated traits in Italian and Spanish varieties during the 20th century. Euphytica 155, 259-270.

Royo, C., Martos, V., Ramdani, A., Villegas, D., Rharrabti, Y. \& García Del Moral, L. F. (2008). Changes in yield and carbon isotope discrimination of Italian and Spanish durum wheat during the 20th century. Agronomy Journal 100, 352-360.

Royo, C., Maccaferri, M., Álvaro, F., Moragues, M., Sanguineti, M. C., Tuberosa, R., Maalouf, F., García Del 
Moral, L. F., Demontis, A., Rhouma, S., Nachit, M., Nserallah, N. \& Villegas, D. (2010). Understanding the relationships between genetic and phenotypic structures of a collection of elite durum wheat accessions. Field Crops Research 119, 91-105.

Salvi, S., Porfiri, O. \& Ceccarelli, S. (2012). Nazareno Strampelli, the 'Prophet' of the Green Revolution. Journal of Agricultural Science, Cambridge. Published online, doi: $10.1017 /$ S0021859612000214.

Sanchez-Garcia, M., Álvaro, F., Martín-Sánchez, J. A., Sillero, J. C., Escribano, J. \& Royo, C. (2012). Breeding effects on the genotype $\times$ environment interaction for yield of bread wheat grown in Spain during the 20th century. Field Crops Research 126, 79-86.

SAS Institute Inc. (2009). SAS/STAT 9.2. User's Guide, 2nd edn. Cary, NC: SAS Institute Inc.

SAYRE, K. D. (1996). The role of crop management research at CIMMYT in addressing bread wheat yield potential issues. In Increasing Yield Potential in Wheat: Breaking the Barriers (Eds M. P. Reynolds, S. Rajaram \& A. McNab), pp. 203-207. Mexico, DF: CIMMYT.

Sener, O., Arslan, M., Soysal, Y. \& Erayman, M. (2009). Estimates of relative yield potential and genetic improvement of wheat cultivars in the Mediterranean region. Journal of Agricultural Science, Cambridge 147, 323-332.

Shearman, V.J., Sylvester-Bradley, R., Scott, R. K. \& FOULKES, M. J. (2005). Physiological processes associated with wheat yield progress in the UK. Crop Science $\mathbf{4 5}$, 175-185.
Siddique, K. H. M., Belford, R. K., Perry, M. W. \& Tennant, D. (1989). Growth, development and light interception of old and modern wheat cultivars in a Mediterranean-type environment. Australian Journal of Agricultural Research 40, 473-487.

Siddique, K. H. M., Tennant, D., Perry, M. W. \& Belford, R. K. (1990). Water use and water use efficiency of old and modern wheat cultivars in a Mediterranean-type environment. Australian Journal of Agricultural Research 41, 431447.

Voltas, J., López-Córcoles, H. \& Borrás, G. (2005). Use of biplot analysis and factorial regression for the investigation of superior genotypes in multi-environment trials. European Journal of Agronomy 22, 309-324.

Waddington, S. R., Ransom, J.K., Osmanzal, M. \& SAUNDERS, D. A. (1986). Improvement in the yield potential of bread wheat adapted to Northwest Mexico. Crop Science 26, 698-703.

Worland, A.J. \& SNAPE, J.W. (2001). Genetic basis of worldwide wheat varietal improvement. In The World Wheat Book: a History of Wheat Breeding (Eds A.P. Bonjean \& W.J. Angus), pp. 59-100. Paris: Lavoisier Publishing Inc.

Worland, A. J., Korzun, V., Röder, M.S., Ganal, M. W. \& LAW, C. N. (1998). Genetic analysis of the dwarfing gene Rht8 in wheat. Part II. The distribution and adaptive significance of allelic variants at the Rht8 locus of wheat as revealed by microsatellite screening. Theoretical and Applied Genetics 96, 1110-1120. 